\title{
Land Application of Biosolids in the USA: A Review
}

\author{
Qin Lu, Zhenli L. He, and Peter J. Stoffella \\ Indian River Research and Education Center, University of Florida, 2199 S Rock Road, Fort Pierce, FL 34945, USA \\ Correspondence should be addressed to Zhenli L. He, zhe@ufl.edu
}

Received 2 February 2012; Revised 29 May 2012; Accepted 12 June 2012

Academic Editor: Silvana I. Torri

Copyright (C) 2012 Qin Lu et al. This is an open access article distributed under the Creative Commons Attribution License, which permits unrestricted use, distribution, and reproduction in any medium, provided the original work is properly cited.

Land application of biosolids has proven a cost-effective method of waste disposal by beneficially recycling organic matter and nutrients and improving soil quality; however, it may also pose potential threat to the environment and human health. The purpose of this paper is to provide information on recent research progresses and regulation efforts regarding land application of biosolids, including forms and types and nutrient values of biosolids, environmental and health concerns, and related best management practices (BMPs) of biosolids application, with emphasis on its land application in agriculture. More research and regulations are expected to minimize potential risks of biosolids land application, especially its long-term impacts.

\section{What Are Biosolids?}

Fifty years ago, partially treated wastewaters from thousands of US cities were discharged into the nation's rivers, lakes, and bays. These receiving water bodies became heavily polluted [1]. Since 1950s, federal legislation has been strengthened to control water pollution. Municipal sewage treatment systems or publicly owned treatment works (POTWs) were built, although ocean disposal of residual solids was still permitted. The Federal Water Pollution Control Act Amendments of 1972 (PL 92-500, 1972) placed further restrictions on the discharge of wastewater to waterways and encouraged other disposal methods such as land applications. Recent restrictions on ocean disposal (Ocean Dumping Ban Act, 1988) and cost increase of incineration and landfill make land application an attractive option of disposal.

Wastewater usually undergoes two processes in treatment factories. The primary step is a physical screening or settling process to remove sediment but with all the dissolved minerals still in the effluent. The secondary step is a biological process where dissolved biological matter is progressively converted into a solid mass using a cultivated culture of indigenous, water-borne bacteria, thereby large amount of biological oxygen demand (BOD) is removed from the wastewater. A tertiary step, which is a chemical and/or biological process, may also be employed to remove nutrients especially $\mathrm{N}$ and $\mathrm{P}$, which are the main concern of eutrophication of waters [2]. After the tertiary step, the effluent may be suitable for discharge into a stream, river, lagoon, or wetland or used for irrigation of public area such as golf courses, greenways, or park or injection to groundwater.

To meet the regulatory requirements (40 CFR Part 503, described below) for land application, the wastewater treatment residuals (sewage sludge) have to undergo treatments to reduce pathogens and attractiveness to vectors. Treatments include aerobic digestion, anaerobic digestion, composting, alkaline stabilization, and thermal drying. They may be also used to control odor and inactivate heavy metals. Biosolids is the term created in 1991 by the Name Change Task Force at Water Environment Federation (WEF), the water and wastewater industry's main trade and lobby organization in the USA, to distinguish treated sewage sludge from raw sewage sludge and facilitate land application of processed sewage sludge that would be more acceptable to the public. Biosolids are sewage sludges that have undergone treatments in accord with prevailing federal, state, and local regulations to permit its land application and are defined by the US Environmental Protection Agency (EPA) as "the nutrientrich organic materials resulting from the treatment of sewage sludge" [3].

\section{Regulations}

Regulations that ensure the safe and responsible management of sludge have been in effect since 1970s. As a result, 
sludge quality has dramatically improved since then. The Clean Water Act amendments of 1977 and 1987 and the Ocean Dumping Ban Act of 1988 (P.L. 100-688) prohibit ocean dumping of sludge and require controls on sludge use and disposal. Regulations entitled "The Standards for the Use or Disposal of Sewage Sludge" were developed and published by the US EPA on Feb. 19, 1993 as the 40 CFR (Title 40, Code of Federal Regulations) Part 503 Biosolids Rule (Part 503 Rule) and became effective on March 22, 1993. The law has become known as the "503 Rule" [4]. The 503 Rule is based on the results of risk assessments for chemicals that began in the mid-1970s, was more extensive than any previous federal rulemaking effort for sludge, and established biosolids quality requirements for its land application. These requirements address pathogen and vector attractiveness reduction, metal loading and concentration limits, and nutrient limits [4].

2.1. Pathogens and Vector Attractiveness. As pathogens (e.g., bacteria, viruses, protozoa, helminths) can cause diseases, pathogens in biosolids are required by the 503 Rule to be reduced prior to land application to minimize potential for diseases. There are two classes of pathogen reduction: Class A and Class B. Class A pathogen reduction is necessary if biosolids are to be applied to lawns, home gardens, or other types of land, or bagged for sale, or land application and requires pathogen densities be reduced to below detection limits: less than 3 MPN per 4 grams total solids biosolids (dry weight basis) for density of Salmonella sp., less than 1 PFU per 4 grams total solids biosolids (dry weight basis) for enteric viruses, and less than 1 viable helminth ova per 4 gram total solids biosolids (dry weight basis) for viable helminth ova [5]. There are 6 alternative methods for meeting Class A pathogen reduction requirement: specific timetemperature regimes, high $\mathrm{pH}$-high temperature process, other processes, unknown processes, processes to further reduce pathogens (PFRPs), and a process equivalent to PFRP [5].

Class B pathogen reduction is necessary for any other application and requires a fecal coliform density in the treated sewage sludge (biosolids) of 2 million MPN or CFU per gram total solids biosolids (dry weight basis) [5]. Viable helminth ova are not necessarily reduced in Class B biosolids. There are 3 alternatives for achieving Class B pathogen reduction: the geometric mean fecal coliform density of 7 treated samples must be less than 2 million CFU or MPN per gram of biosolids (dry weight basis), use of a process of PSRPs, and use of processes equivalent to PSRP [5].

Public access is not restricted for biosolids that meet Class A requirements. Since Class B sewage sludge still contains considerable pathogens, site restrictions that limit crop harvesting, animal grazing, and public access for a certain period of time are required.

As vectors (e.g., rodents, birds, insects) can spread diseases by harboring and transferring pathogens, reducing the attractiveness of biosolids to vectors reduces the potential for transmitting diseases from pathogens in biosolids. Part 503 regulation contains 12 options for demonstrating
TABLE 1: Pollutant ceiling concentrations and cumulative loading amounts for biosolids (adapted from [6]) and mean concentrations measured in biosolids from the National Sewage Sludge Survey [7].

\begin{tabular}{lccc}
\hline Trace metal & $\begin{array}{c}\text { Ceiling } \\
\text { concentration } \\
\text { limit }(\mathrm{ppm})^{\mathrm{a}}\end{array}$ & $\begin{array}{c}\text { Cumulative } \\
\text { pollutant limit } \\
\text { loading }\left(\mathrm{kg} \mathrm{ha}^{-1}\right)\end{array}$ & $\begin{array}{c}\text { Mean } \\
(\mathrm{ppm})\end{array}$ \\
\hline Arsenic (As) & 75 & 42 & 10 \\
Cadmium (Cd) & 85 & 39 & 7 \\
Copper (Cu) & 4300 & 1503 & 741 \\
Lead (Pb) & 840 & 301 & 134 \\
Mercury (Hg) & 57 & 17 & 5 \\
Molybdenum (Mo) & 75 & $-{ }^{\mathrm{b}}$ & 9 \\
Nickel (Ni) & 420 & 421 & 43 \\
Selenium (Se) & 100 & 100 & 5 \\
Zinc (Zn) & 7500 & 2805 & 1202 \\
\hline
\end{tabular}

ary weight basis.

bThe February 25, 1994 Part 503 Rule amendment deleted the molybdenum cumulative limit loading for sewage sludge applied to agricultural land but retained the molybdenum ceiling concentration.

a reduction in vector attraction of sewage sludge: reduction in volatile solids content, additional digestion of anaerobically digested sewage sludge, additional digestion of aerobically digested sewage sludge, specific oxygen uptake rate (SOUR) for aerobically digested sewage sludge, aerobic processes at higher than $40^{\circ} \mathrm{C}$, addition of alkali, moisture reduction of sewage sludge containing no unstabilized solids, moisture reduction of sewage sludge containing unstabilized solids, injection, incorporation of sewage sludge into the soil, covering sewage sludge, and raising the $\mathrm{pH}$ of domestic septage [5]. Options 1 through 8 and Option 12 are designed to reduce the attractiveness of sewage sludge to vectors, while Options 9 through 11 are to prevent the vectors from coming in contact with the sewage sludge.

2.2. Trace Elements. Trace elements in biosolids are of particular concern in regard to their effects on human and animal health. The US EPA [8] analyzed their risks to humans, animals, plants, and soil organisms from exposure to pollutants in biosolids via 14 different pathways for land-applied biosolids. Nine trace elements: arsenic (As), cadmium $(\mathrm{Cd})$, copper $(\mathrm{Cu})$, lead $(\mathrm{Pb})$, mercury $(\mathrm{Hg})$, molybdenum (Mo), nickel $(\mathrm{Ni})$, selenium $(\mathrm{Se})$, and zinc $(\mathrm{Zn})$, were deemed to be of sufficient risk to regulate. Land application of biosolids must meet the ceiling concentrations and cumulative loading rates for these 9 trace elements set in the 503 Rule (Table 1). If the concentration limit of any one of these elements is exceeded, the biosolids cannot be landapplied. The application of biosolids will also be required to cease, if it is estimated that the cumulative loading limit is being approached.

Biosolids that meet Class A pathogen reduction requirements, metals limits (pollutant concentrations), and vector control requirements are considered to be "Exceptional Quality" (EQ) biosolids. Exceptional quality biosolids can be used with few site restrictions except following normal agronomic practices. 
For biosolids that do not meet EQ standards, certain management practices are required: for example, do not apply to flooded or frozen land; apply at agronomic rates for $\mathrm{N}$; stay 10 meters from waterways; must not harm endangered species.

2.3. Nutrients. Although maximum nutrient application rates in federal biosolids regulations are not well defined, the 503 Rule stipulates that agronomic rates cannot be exceeded. To protect groundwater or surface water quality, nitrogen is regulated through an agronomic rate approach, requiring an estimate of crop $\mathrm{N}$ need and biosolids $\mathrm{N}$ availability [8]. Biosolids P applications are not regulated by the US EPA, but increasing numbers of states are introducing regulations, because of concerns about the effects of repeated manure or biosolids applications on soil $\mathrm{P}$ and risk of $\mathrm{P}$ loss to surface water. Maryland's Water Quality Improvement Act is the first state law in the Mid-Atlantic region to regulate land applications of biosolids $\mathrm{P}$ in the same manner as fertilizer and manure P [9]. And Shober and Sims in 2003 [10] recommended a national biosolids P risk assessment be conducted to develop scientifically based national standards for P management.

\section{Forms and Types}

There are a large number of different forms of biosolids products including liquid, cake, and pellet form. Liquid biosolids may come directly from the digester without going through any dewatering/drying process, thus usually having high water content (94-97\%) and a low dry solid content (3-6\%) [11]. Cake biosolids with the texture of a wet sponge can be created with digested liquid sludge or undigested liquid sludge alkali-stabilized with quicklime (calcium oxide) or hydrated lime (calcium hydroxide). Cake biosolids usually have a solids content of $11-40 \%$. Pellet biosolids are produced by heating and dying to a solid content of more than $90 \%$.

From liquid to cake to pellet form, both volume and weight of biosolids are subsequently reduced, increasing economic value by reducing transportation or storage costs. Pellet biosolids can be easily handled and spread with conventional agricultural equipments.

Since soluble anions and cations are left in the liquid phase, nutrient composition can be changed in the dewatering processes during the production of cake and pellet biosolids. For instance, ammonium dominates the inorganic $\mathrm{N}$ in dewatered biosolids. Many nutrients may be dominated by less bioavailable forms in dewatered biosolids therefore, the loss of nutrients would be less from a dewatered biosolids than from a liquid biosolids when applied to soils [12]. Dewatered biosolids are more persistent but slower in nutrient release, while liquid biosolids are faster in providing nutrients for plant uptake.

\section{Nutrient Value of Biosolids}

Biosolids are a valuable source of nutrients although it contains lower N (2-8\%), P (1.5-3\%), and K (0.1-0.6\%)
TABLE 2: Means and variability of nutrient concentrations ${ }^{\mathrm{a}}$ in biosolids collected and analyzed in Pennsylvania between 1993 and 1997 [12].

\begin{tabular}{lccccc}
\hline Nutrient & $\begin{array}{c}\text { Total } \\
\text { Kjeldahl N } \\
(\%)\end{array}$ & $\begin{array}{c}\mathrm{NH}_{4} \text {-N } \\
(\%)\end{array}$ & $\begin{array}{c}\text { Organic N } \\
(\%)\end{array}$ & $\begin{array}{c}\text { Total P } \\
(\%)\end{array}$ & $\begin{array}{c}\text { Total K } \\
(\%)\end{array}$ \\
\hline $\begin{array}{l}\text { Mean } \\
\text { Standard } \\
\text { deviation }\end{array}$ & 4.74 & 0.57 & 4.13 & 2.27 & 0.31 \\
\hline
\end{tabular}

${ }^{a}$ Concentrations are on a dried solids basis.

compared to commercial fertilizers, especially high-grade ones $[13,14]$. A survey of nutrient levels in biosolids conducted by Stehouwer et al. [15] using more than 240 samples collected and analyzed from 12 POTWs in Pennsylvania between 1993 and 1997 showed average N, P, and K contents of $4.74 \%, 2.27 \%$, and $0.31 \%$, respectively (Table 2 ). These biosolids were aerobically digested, anaerobically digested, or alkali-treated.

Around $50-90 \%$ of $\mathrm{N}$ in biosolids is in organic compounds [16]. Processes such as digestion or composting result in the loss of organic $\mathrm{N}$ because the readily degradable organic matter undergoes mineralization during digestion or composting. For instance, a loss of $\mathrm{N}$ by $15.6 \%$ via ammonia volatilization was observed in biosolids composting [17].

Phosphorus is largely present as inorganic phosphates of $\mathrm{Fe}, \mathrm{Al}$, and $\mathrm{Ca}$. For example, in the biosolids used by Shepherd and Withers [18], 72\% of total P was HClextractable, $33 \%$ was $\mathrm{NaHCO} 3$-extractable, $23 \%$ was $\mathrm{NaOH}$ extractable, and $18 \%$ was water soluble. Hydrochloric acidextractable $\mathrm{P}$ was mainly associated with $\mathrm{Ca}$, while $\mathrm{NaHCO} 3$ and $\mathrm{NaOH}$-extractable $\mathrm{P}$ were mainly associated with $\mathrm{Al}$ and Fe [19]. The relatively small content of $\mathrm{H} 2 \mathrm{O}$-extractable $\mathrm{P}$ may be due to the $\mathrm{Fe}, \mathrm{Al}$, and $\mathrm{Ca}$ in biosolids which are added during the treatment processes as metal salts and lime [20]. Compared to manures, biosolids have a lower N-to-P ratio, around 3.1-3.4 [18]. Biosolids have limited amount of $\mathrm{K}$ [21], which is partitioned into the aqueous fraction or effluent at the wastewater treatment plant.

Biosolids contain several essential micronutrients for plants (e.g., B, Cl, Cu, Fe, Mn, Mo, and $\mathrm{Zn}$ ) which are not provided by most conventional chemical fertilizers [22, 23]. Therefore, biosolids can be applied on micronutrientdeficient soils (e.g., alkaline soils [24], sandy soil [25]).

Nutrient values of biosolids vary with sources of wastewater and wastewater treatment processes. Processes such as digestion or composting result in the loss of organic matter through decomposition, increase concentrations of $\mathrm{P}$ and trace metals, decrease ammonia- $\mathrm{N}$ by volatilization, and decrease $\mathrm{K}$ by leaching. Lime-stabilized biosolids contain lower N, P, and metal concentrations, but higher Ca concentration than digested biosolids, due to the large amount of lime added to the material.

However, nutrient composition of biosolids is significantly altered by stabilization processes. The rate of nutrient release (or mineralization) is also affected by the processes. Mineralization of $\mathrm{N}$ from aerobically digested biosolids (e.g., $32.1 \%$ ) was reported to be significantly higher than that from anaerobically digested biosolids (e.g., 15.2\%) [26, 27]. 
Besides, soil type [26], temperature [28], soil moisture content, aeration, and species and number of soil microorganisms play a role in organic matter mineralization in biosolids. More $\mathrm{N}$ in municipal biosolids was mineralized in a Dystrochrept soil, whereas more $\mathrm{N}$ in pulp and paper industrial biosolids mineralized in a Typic Udivitrand soil [27]. Mineralization of $\mathrm{N}$ was significantly higher at $20^{\circ} \mathrm{C}$ (average 22.8\%) than at $10^{\circ} \mathrm{C}$ (average 9.7\%) [27]. Mineralization rate is also closely related to $\mathrm{C}: \mathrm{N}$ ratio. The higher the $\mathrm{C}: \mathrm{N}$ ratio, the lower the $\mathrm{N}$ mineralization rate. In some cases, the mineralization process was more influenced by soil type than by rate and type of sludge applied [26].

The primary nutrients in biosolids are in organic forms, not as soluble as those in chemical fertilizers, and released more slowly. Therefore biosolids can nourish the plants at a slower rate over a longer period of time with higher use efficiency and a lower likelihood of polluting groundwater when applied rate is appropriate.

Although maximum nutrient application rates in federal biosolids regulations are not well defined, the 503 Rule stipulates that agronomic rates cannot be exceeded. Also groundwater or surface water is not permitted to be contaminated by biosolids applications.

\section{Land Application of Biosolids: Benefits}

Due to population increase and urbanization, biosolids production has been on the rise. And land application is generally considered the most economical and beneficial way of biosolids disposal [29]. The most recent national biosolids survey indicated that about 6.5 million dry metric tons of biosolids were produced in the US and approximately $60 \%$ of the total (i.e., 4 million dry tons) were land-applied to soils in the US in the year 2004 alone [30]. US EPA estimates that biosolids are applied to approximately $0.1 \%$ of available agricultural land in the United States on an annual basis [31].

Biosolids are nutrient-rich organic materials with an organic matter content of up to $50 \%$. Therefore, biosolids can be utilized as a soil conditioner to improve physical, chemical, and biological properties of soils, especially those degraded or disturbed soils. Besides acting as a food source for microorganisms, organic materials are the major binding agents for aggregate formation and stabilization [32]. Optimum soil structure, in turn, improves many other important soil physical and chemical properties such as bulk density, porosity, water and cation exchange capacity, aeration and drainage, microbial communities and soil fauna, thus contributing to disease suppression, and reduced soil erosion [33].

In a 4-year trial with a sandy loamy silt soil by Krause [34], aggregate size and stability increased with increased soil organic matter (OM) after biosolids (2-4\% DM content) incorporation. Similar results were also reported by Lindsay and Logan [35] in a 4-year trial where anaerobically digested biosolids are applied to a silt loam soil at 11 rates ranging from 0 to $300 \mathrm{Mg} \mathrm{ha}^{-1}$. Bulk density significantly decreased, and porosity, moisture retention, percentage of water-stable aggregates, mean weight diameter of aggregates, and liquid and plastic limits increased in the surface soils $(0-15 \mathrm{~cm})$ with biosolids application. Increase in aggregate stability was related to the increased organic $\mathrm{C}$ in the soil incorporated with biosolids [36].

Reduced bulk density and improved water holding capacity in the short-term [37] may be mainly due to biosolids' direct dilution effect, its high organic matter content, and partly due to its effect on aggregate formation and stabilization. Improved pore size distribution by long term application of biosolids in soil may be linked to the increased volume of macropores or micropores, depending on the texture of the soil $[38,39]$. Biosolids-treated soil was less sensitive to compaction than untreated soil due to the improved pore volume [34].

Improvements in soil physical properties after biosolids application coincided with an increase in soil organic C $[34,35,38]$. Many of the soil physical properties differences were associated with addition of organic matter, and these effects persisted for at least 4 years according to Lindsay and Logan [35]. Regression analysis indicated that approximately $80 \%$ of the observed variations in the percent water holding capacity increases, at both field capacity and wilting point, could be attributed to variations in soil texture and soil organic C increases [40]. In a sandy and poorly buffered soil, $10 \mathrm{tha}^{-1} \mathrm{y}^{-1}$ or $100 \mathrm{tha}^{-1}$ of urban biosolids incorporated every 2 years for 20 years resulted in a 2.5 -fold increase in organic C content [41].

Biosolids have the advantage of high organic matter content and have been used to remediate sites previously contaminated with trace metals by binding and converting the metals to less soluble fractions $[42,43]$.

Soil degradation mainly involves damage to soil structure [44]. Due to the beneficial effects of biosolids on soil structure, interest in using biosolids on degraded soils, such as metal-contaminated mine tailings, disturbed urban soils, landfill cover soils, and eroded land to reestablish the vegetation and the ecosystem, is on the rise. Turf grass establishment on a disturbed urban soil with low organic matter and nutrient contents was significantly $(P<0.05)$ enhanced by biosolids application [45]. Other similarly beneficial effects of biosolids application on degraded soils, such as increased aboveground plant biomass yield [46], restored vegetative cover [37, 43], and reestablished ecosystem viability with active microbial communities [47] were also reported.

Besides improving soil quality, biosolids application can supplement or replace commercial fertilizer. Biosolids addition increased total soil $\mathrm{N}$ concentration and extractable $\mathrm{P}$ in comparison with fertilizers with the additional benefit that a fraction of the $\mathrm{N}$ added in the biosolids had been conserved in the systems through partitioning to soil organic matter [48]. Composted biosolids supply plant available Fe and may represent a sustainable alternative to more costly chelated Fe fertilizers used in soils with elevated $\mathrm{pH}$ [49].

An advantage of using biosolids to supplement or replace fertilizer is its ability to slow-release nutrients. Biosolids release $\mathrm{N}$ and other nutrients over several growing seasons as soil bacteria slowly process through decomposition 
(i.e., residual effect). Binder et al. [50] reported that approximately $40,20,10$, and $5 \%$ of the total biosolids- $\mathrm{N}$ were recovered by the crops in the 1st, $2 \mathrm{nd}, 3 \mathrm{rd}$, and 4th year, respectively, after a single biosolids application. The relative yield increase was $33 \%, 21 \%, 14 \%$, and $9 \%$ in the 1st, 2 nd, $3 \mathrm{rd}$, and 4th year, respectively, after application. Slow release of nutrients is more beneficial to crops as the nutrients become available when needed, while most nutrients in commercial fertilizers are water soluble, readily subjected to leaching losses if they are not rapidly taken up by the crops, especially $\mathrm{N}$. Therefore, the use of biosolids as an $\mathrm{N}$ source is being considered as one of the best management practices (BMPs) for $\mathrm{N}$ management in Florida citrus groves [51].

Studies have shown that application of biosolids resulted in similar or higher yields than inorganic fertilizers [52], especially when applied for multiple years [53]. In a 4year study, biosolids and urea were applied for the first 2 years, and prairie grass (Bromus willdenowii Kunth) in the biosolids-applied plots began to produce higher yields than that in the urea-applied plots from the 2nd year [53]. Higher grain and straw yield of wheat (Triticum aestivum) and higher concentrations of elements ( $, \mathrm{P}, \mathrm{K}, \mathrm{Fe}, \mathrm{Zn}, \mathrm{Mn}$, $\mathrm{Cu}, \mathrm{Co}, \mathrm{Cd}$, and $\mathrm{Pb}$ ) in wheat plant were observed with biosolids treatment as compared to control [54]. Nutrient uptake and crop growth enhancement with biosolids were also reported by Brown et al. [48]. Biosolids composts as horticultural substrates have been widely used in vegetable crop transplant production. The benefits have been reported by several researchers (Table 3 ).

Alkali-stabilized biosolids can be used as liming material to alleviate soil acidity and $\mathrm{Al}$ toxicity. $\mathrm{pH}$ was increased from 5.7 to 6.9 for an acid clay sandy loam and from 4.5 to 6.0 for a strongly acid sandy loam, while potassium chlorideextractable Al was decreased from 0.1 to $0.0 \mathrm{cmol} \mathrm{kg}^{-1}$ for the former soil and from 4.0 to $0.1 \mathrm{cmol} \mathrm{kg}^{-1}$ for the latter soil [55]. As a result, barley (Hordeum vulgare) showed better growth and higher grain yield in the biosolids-amended plots as compared to the unamended control [55]. Alkalinestabilized dewatered biosolids were observed to have a liming value of $300 \mathrm{~g} \mathrm{~kg}^{-1} \mathrm{DM} \mathrm{CaCO}_{3}$ equivalent on average [56].

In addition to increasing yield, biosolids application improves forage quality by correcting trace metal imbalances. Native grass species in Colorado rangelands had low $\mathrm{Cu}$ to-Mo ratios $(<1.2: 1)$ before biosolids application [57], which induced $\mathrm{Cu}$ deficiencies in cattle and sheep [58]. After receiving a one-time application of biosolids from 5 to $40 \mathrm{Mgha}^{-1}$, Cu-to-Mo ratios in the forage from the biosolids-treated plots increased above the $2: 1$ ratio recommended by Miltimore and Mason [58], which corrected $\mathrm{Cu}$ deficiency in cattle and sheep [57].

\section{Land Application of Biosolids: Precautions}

Concerns and negative reports on biosolids application are related not only to that sludge contains heavy metals or organic compounds found in wastewaters from domestic and industrial sources but also to that excessive nutrients cause eutrophication of waters. And more than often, odors
TABLE 3: Benefits of biosolids composts used in growing media for vegetable transplants (modified from [59]).

\begin{tabular}{|c|c|c|}
\hline Compost $^{\mathrm{a}}$ & Growth response & Reference \\
\hline BS & $\begin{array}{l}\text { Tomato and cabbage dry wt. and stem } \\
\text { diameter = peat-lite }\end{array}$ & {$[60]$} \\
\hline BS & $\begin{array}{l}\text { Broccoli, cabbage, eggplant, lettuce, pep- } \\
\text { per, and tomato dry wt. increased linearly } \\
\text { over } 8 \text {-week period }\end{array}$ & {$[61]$} \\
\hline BS & $\begin{array}{l}\% \text { emergence slightly }<\text { peat-lite, plant } \\
\text { height }>\text { peat-lite }\end{array}$ & {$[62]$} \\
\hline BS/MSW & Lettuce and cabbage dry wt. = peat-lite & {$[63]$} \\
\hline $\mathrm{YT}+\mathrm{BS}$ & $\begin{array}{l}\text { Tomato dry wt., leaf area, and stem diame- } \\
\text { ter > peat-lite }\end{array}$ & {$[64]$} \\
\hline
\end{tabular}

aS: biosolids; MSW: municipal solid waste; YT: yard trimmings.

and pathogens are the concerns preventing the public from accepting biosolids land application. Therefore, precautions need to be taken in these aspects.

6.1. Odors. For some reason, federal biosolids regulations do not regulate odors. Unfortunately, odor is one of the reasons for lack of public acceptance and complaints of biosolids when land-applied. And odor complaints among other concerns have led to a dramatic increase in local ordinances that ban or restrict the use of biosolids in recent years. Although more research is needed to identify potential health effects of biosolids odors, nuisance odors can have detrimental effects on aesthetics, property values, and the quality of life in communities subjected to them. So, eliminating or mitigating odors is among the great challenges in gaining public acceptance of biosolids. Although many of the odor-causing bacteria in biosolids have been destroyed in the biosolids stabilization process, some actions can be taken to control odors at land application sites. Some of these steps could include actions such as minimizing the length of time biosolids are stored selecting remote sites and fields away from neighbors, directly covering or incorporating biosolids into the soil, cleaning tanks, trucks, and equipment daily, and avoiding land application when wind conditions favor transport of odors to residential areas [65].

6.2. Excess Loading of $P$ and Other Nutrients. Because of a relatively low $\mathrm{N}: \mathrm{P}$ ratio (about 3.1-3.4) [18], which is also lower than optimal for crop growth, application of biosolids based on crop $\mathrm{N}$ requirement can result in buildup of $\mathrm{P}$ in soil and subsequent $\mathrm{P}$ transport to surface or subsurface waters as dissolved and particulate $\mathrm{P}$, causing eutrophication [66]. Therefore, an optimum P management practice is to apply biosolids based on crop $\mathrm{P}$ requirement. According to the laboratory characterization by Ajiboye et al. [20] and $\mathrm{He}$ et al. [21], labile $\mathrm{P}$ fractions in biosolids are significantly smaller than other P sources (e.g., fertilizers, manure, and yard waste). Furthermore, labile P fractions are different in biosolids stabilized by different processes. Biosolids produced via biological P removal (BPR) processes have higher labile $\mathrm{P}$ fractions than those produced by digestion or composting [67]. In biosolids, Fe-associated P 
is less susceptible to loss than $\mathrm{Al}$-associated $\mathrm{P}$, which is less susceptible than Ca-associated P. Iron-and Al-bound P can shift to Ca-P and soluble $\mathrm{P}$ when sludge is treated with lime [68]. Most of the P in biosolids is in a recalcitrant form, suggesting that biosolids $\mathrm{P}$ may be less subjected to runoff loss as compared with other amendments when applied to agricultural lands as runoff $\mathrm{P}$ is positively related to the amounts of $\mathrm{P}$ extracted by either water or $\mathrm{NaHCO}_{3}$ [69]. Phosphorus loss from soil also depends on the degree of $\mathrm{P}$ saturation (DPS) in soil or, more importantly, the soil $\mathrm{P}$ storage capacity (SPSC). If the soil is more saturated with $\mathrm{P}$ or has a low SPSC, it will have less capacity to retain added $\mathrm{P}$ and more susceptible to losses of $\mathrm{P}$ in runoff and leachate [70-73]. Coarse-textured soils have a low P adsorption capacity due to low contents of clay and reactive $\mathrm{Fe}$ and $\mathrm{Al}$ oxide in the soil [74]. Application of $\mathrm{Fe}$ - or Albiosolids can increase the SPSC to provide additional sites for $\mathrm{P}$ adsorption $[68,75]$.

Nitrate $\mathrm{N}$ concentration higher than the maximum contaminant limit (MCL, $10 \mathrm{mg} \mathrm{NO}_{3}-\mathrm{N} \mathrm{L}^{-1}$ ) for drinking water established by US EPA [76] is detected when high application rate of biosolids is used especially on coarsetextured soil and mine reclamation [77-79].

As mentioned previously, biosolids application can increase $\mathrm{Cu}$-to-Mo ratio and correct $\mathrm{Cu}$ deficiency in ruminant animals [57], but often Mo availability is also increased by biosolids application, and its increase outcompetes $\mathrm{Cu}$ and suppresses $\mathrm{Cu}$ uptake by the animals, especially from the alkaline-stabilized biosolids applications [80].

6.3. Heavy Metals. There is public concern about the heavy metal pathways after entering the soil with biosolids land application: they may accumulate to hazardous levels in the soil after repeated application of biosolids, and they may migrate from the site to surface or subsurface waters.

Regarding metal behavior and fate in soils, its uptake by plants, and transfer along the food chain, there are plateau, time bomb, and soil-plant barrier hypotheses. The plateau hypothesis considers that the trace metals are so tightly held by the organic matter in biosolids and hydrous oxides of $\mathrm{Fe}$ and $\mathrm{Mn}$ and clays in the soil that their bioavailability or toxicity is greatly decreased and that they are retained in the soil's surface horizon, or in the plow layer instead of being taken up by plants or leaching down the soil profile. Therefore, the metal concentrations of plant tissue will reach a plateau as biosolids mass loading increases and remain at this plateau after termination of sludge application [81]. Reports both for and against this theory have been published. In a field trial reporting the results of 14 years of continuous, heavy biosolids applications, Dowdy et al. [82] reported that more than $50 \%$ of trace metals were so strongly adsorbed that they could be extracted only with a very strong nitric acid digest. At application rates up to 476 dry tons ha ${ }^{-1}$, trace metals remained mainly in the zone of incorporation, even during long-term application. At application rates less than 100 dry tons ha ${ }^{-1}$, essentially no movement of heavy metals was observed [83]. However, McBride et al. [84] reported that the high-Fe and high-Al sludge amendments did not improve the soils' affinity for Cd. Subsurface transport of $\mathrm{Cd}, \mathrm{Cr}$, and Mo can be mediated by biosolids colloids with average metal elution in association with biosolids colloids ranging from 65 to $80 \%$ of the input metal concentration $[85,86]$.

Some scientists support the "time bomb model", arguing that these metals could be released and become available and toxic to plants (thus a time bomb) with time following termination of biosolids application and the organic matter undergoes biodegradation [87, 88].

Data obtained from repeated applications of biosolids over 10 years did not indicate an increase in Cd concentration in plant tissue or from organic matter breakdown over time even at loading doses reaching $1,080 \mathrm{t} \mathrm{ha}^{-1}$ [89]. These results support the soil-plant barrier theory and indicate that plants play an important role in protecting the general food chain since they tend to provide an effective barrier against the uptake of most trace metals. But biological activities in the soil may be negatively impacted by biosolids. McGrath and coworker $[90,91]$ have published a series of papers on this topic. The amount of both free-living and symbiotic $\mathrm{N}_{2}$ fixing organisms was decreased [92]. In contrast, Zerzghi et al. [93] reported that 20 consecutive years of Class B biosolids application to arid southwestern desert soils in Arizona had no deleterious effect on soil microbial diversity.

6.4. Organic Pollutants. Synthetic organic compounds used in food production, personal care products, plastics manufacturing, and other industrial processes such as flame retardants (e.g., TBB, TBPH), dioxins, and steroid hormones may end up in biosolids $[94,95]$ and migrate to the natural environment $[96,97]$. Many of these compounds are toxic or carcinogenic to organisms exposed to critical concentrations over certain periods of time, and their presence in biosolids causes great concern also because they are persistent, difficult to degrade, and they bioaccumulate. But no organic chemicals are currently regulated under Part 503 just because the chemical has been banned for use and manufacturing in the USA, or it has been detected in $5 \%$ or fewer of the sludges tested in the National Sewage Survey, or the 1-in-10,000 cancer risk limit was less than the concentration measured in $99 \%$ of the sludges tested [94].

6.5. Pathogens. In biosolids, the primary source of pathogens is human wastes. Pathogens are generally classified as primary (e.g., bacteria, viruses, protozoa, and helminths) or secondary (e.g., fungi). A primary pathogen can invade and infect a healthy person, whereas a secondary, or opportunistic, pathogen invades and infects highly debilitated or immunosuppressed individuals. Composting, if conducted properly, is a very effective method for disinfection and destruction of pathogens primarily by exposing pathogens to high temperatures (e.g., $55^{\circ} \mathrm{C}$ ) for a prolonged period of time [98]. This temperature-time relationship in composting biosolids is the basis of the US EPA biosolids PFRPs (processes to further reduce pathogens), as stated in 40 CFR Part 503 [4]. The specific pathogen reduction requirement for both Class A and Class B biosolids in Rule 503 is technical 
requirement not based on risk assessment, and Class B biosolids still contain significant levels of pathogens. Incomplete destruction, contamination from external sources, and changes in environmental factors during storage can lead to recurrence of pathogens [99]. Regrowth or reactivation of fecal coliform was observed during incubation and storage of dewatered biosolids by Qi et al. [100]. But the soil environment is generally very hostile to pathogen survival. When biosolids is applied to the soil surface, desiccation and ultraviolet light will destroy the pathogens. If the biosolids are incorporated into the soil, the pathogens' survival will be affected by factors such as $\mathrm{pH}$, organic matter, soil colloidal matter, temperature, and competitive organisms. With proper processes and precaution, the risks from pathogens in biosolids should be minimal.

\section{Best Management Practices (BMPs) for Biosolids}

Best management practices (BMPs) are operating methods that ensure the proper land application of biosolids for protection of the environment and human health. The BMPs include agronomic loading rates, slope limitations, soil $\mathrm{pH}$ limitations, buffer zones, public access restrictions, grazing deferments, soil conservation practices, restrictions for saturated and frozen soils, protection of endangered species, and other site restrictions.

Mismanagement of biosolids can result in $\mathrm{NO}_{3}{ }^{-}$leaching into groundwater [77-79]. Repeated application at high rates can cause accumulation of $\mathrm{P}$ in surface soils, which can increase the risk of runoff/erosion losses of $\mathrm{P}$ to surface water, resulting in eutrophication [76]. Therefore, the Phosphorus Index (P Index) should be taken into consideration when land-applying biosolids. The P Index was developed by the US Department of Agriculture (USDA), Natural Resource Conservation Service (NRCS), as a field-scale tool to assess the potential for off-site P migration [101]. The primary aspects of P Index include consideration of transport factors such as soil erosion, soil runoff class, leaching potential, and distance from a water body along with management factors such as soil test $\mathrm{P}, \mathrm{P}$ application method, and source and rate of $\mathrm{P}$ application [102]. Biosolids application rate should be based on $\mathrm{N}$ application rates if the local $\mathrm{P}$ index is low or medium but should be based on matching $\mathrm{P}$ uptake if the $\mathrm{P}$ index is high and should take account of the nutrient content in the soil, the nutrient requirements of the crop, and how the nutrients will be provided by the biosolids. Taking account of both the initial content of trace elements in the biosolids and in the field is also one of the BMPs requirements on the use of biosolids.

Besides application rate, placement methods can have large effects on nutrient availability and water quality. Redeposition of ammonia volatilized from surface applied biosolids may contaminate surface water and sandy soils. Surface-applying biosolids without incorporation will maximize ammonia volatilization, whereas soil incorporation immediately after application can minimize $\mathrm{N}$ losses. The amounts of $\mathrm{NH}_{3}-\mathrm{N}$ volatilized during a $180 \mathrm{~d}$ incubation period accounted for $18 \%$ of the total mineralized $\mathrm{N}$ for the surface-applied biosolids. Soil incorporation not only increased $\mathrm{N}$ mineralization by more than $60 \%$ in the biosolids but reduced $\mathrm{NH}_{3}$ volatilization by 5 -fold [103]. Also, it is likely advantageous to apply biosolids near the area of maximum root growth.

Timing of application should be based on the local weather and soil type so that nutrient release matches plant need instead of being leached by heavy rain. For instance, in the mid-Atlantic region of the US, loss of $\mathrm{N}$ by leaching was greater, and plant available $\mathrm{N}$ and crop yields were lower when biosolids were applied in mid-December to early January than in March [104]. When the ground is still covered with snow or when rainfall is likely, avoid applications [11].

Studies indicated that $\mathrm{pH}$ is a controlling variable for the redistribution of water-soluble, exchangeable, and nonexchangeable heavy metals in biosolids-applied soils. Zinc solubility increased by biosolids amendment in soils with $\mathrm{pH}<5.0$, while in soils with $\mathrm{pH}>5.8$, biosolids addition, compared with no biosolids addition, lowered the exchangeability of $\mathrm{Zn}$ and favored $\mathrm{Zn}$ partitioning into the nonexchangeable forms [105]. Soil $\mathrm{pH}$ should be taken into consideration when planning biosolids land application to minimize heavy metal pollution risk.

Other BMPs include, but not limited to the following: that microbial analysis of Class A material should be done at the last possible time before application or after storage in order to address the potential repopulation of pathogenic bacteria [106]; that coapplication with water treatment plant residuals (WTRs) can reduce P availability [107]; that nonapplication or buffer zones should be established around surface water bodies, wells, and wetlands; that those sites with slopes in excess of $8-12 \%$ or close to groundwater should be avoided to minimize runoff or leaching, respectively, loss of nutrients and water pollution. Leaving a time period for reaction of the biosolid-borne metals with the soil would be desirable prior to growing a crop [108].

\section{Conclusions and Perspectives}

Land application of biosolids is a beneficial way to recycle organic matter and nutrients, to improve physical, chemical, and biological properties of soils, and to re-establish vegetation and restoration of degraded ecosystem. However, caution needs to be exercised when biosolids are repeatedly applied or at heavy application rates as heavy metals, organic pollutants, and pathogens in biosolids, though at low concentration, may pose a threat to the environment and animal and human health with time. In the future, longterm monitoring is still needed to evaluate the potential impacts of biosolids land application on soil quality and the environment including surface and ground water, air, and plant/animal health as well as food quality. More protective regulations are expected based on scientific monitoring and assessment data. Community-specific outreach programs addressing public risk perceptions to assist solid waste managers in developing and implementing successful biosolids land application systems that are acceptable to the public 
are also needed as a recent descriptive-correlational study conducted in the southeastern United States revealed that the public was inadequately informed about biosolids land application [109].

\section{References}

[1] W. J. Jewell and B. L. Seabrook, "History of land application as a treatment alternative," Tech. Rep. EPA 430/9-79-012, Office of Water Program Operations, Washington, DC, USA, 1979.

[2] R. K. Bastian, "The biosolids (sludge) treatment, beneficial use, and disposal situation in the USA," European Water Pollution Control Journal, vol. 7, no. 2, pp. 62-79, 1997.

[3] U.S. EPA, "Water: sewage sludge (biosolids)," 2011, http:// water.epa.gov/polwaste/wastewater/treatment/biosolids/ index.cfm.

[4] U.S. EPA, "A plain english guide to the EPA part 503 biosolids rule," Tech. Rep. EPA/832-R-93-003, Office of Wastewater Management, Washington, DC, USA, 1994.

[5] U.S. EPA, "Environmental regulations and technology: control of pathogens and vector attraction in sewage sludge," Tech. Rep. EPA/625/R-92/013, U.S. Environmental Protection Agency, Office of Research and Development, National Risk Management Research Laboratory, Center for Environmental Research Information, Cincinnati, Ohio, USA, 2003.

[6] U.S. EPA, "Process design manual: land application of sewage sludge and domestic septage, office of research and development," Tech. Rep. EPA/625/R-95/001, Washington, DC, USA, 1995.

[7] U.S. EPA, "National Sewage Sludge Survey: Availability of Information and Data, and Anticipated Impacts of Proposed Rule on Proposed Regulations, Proposed Rule," Vol. 55, No. 218 Federal Register 47210-83, 1990.

[8] U.S. EPA, "A guide to the biosolids risk assessments for the EPA part 503 rule," Tech. Rep. EPA/832-B-93-005, Office of Wastewater Management, Washington, DC, USA, 1995.

[9] T. W. Simpson, Citizen'S Guide To Maryland'S Water Quality Improvement Act, University of Maryland, College Park, Md, USA, 1998.

[10] A. L. Shober and J. T. Sims, "Phosphorus restrictions for land application of biosolids: current status and future trends," Journal of Environmental Quality, vol. 32, no. 6, pp. 19551964, 2003.

[11] U.S. EPA, Biosolids Technology Fact Sheet: Land Application of Biosolids, Office of Water, Washington, DC, USA, 2000.

[12] T. Bramryd, "Effects of liquid and dewatered sewage sludge applied to a scots pine stand (Pinus sylvestris L.) in Central Sweden," Forest Ecology and Management, vol. 147, no. 2-3, pp. 197-216, 2001.

[13] C. G. Cogger, T. A. Forge, and G. H. Neilsen, "Biosolids recycling: nitrogen management and soil ecology," Canadian Journal of Soil Science, vol. 86, no. 4, pp. 613-620, 2006.

[14] United Nations Industrial Development Organization (UNIDO) and International Fertilizer Development Center (IFDC), Fertilizer Manual, Kluwer Academic Press, Norwell, Mass, USA, 3rd edition, 1998.

[15] R. C. Stehouwer, A. M. Wolf, and W. T. Doty, "Chemical monitoring of sewage sludge in Pennsylvania: variability and application uncertainty," Journal of Environmental Quality, vol. 29, no. 5, pp. 1686-1695, 2000.

[16] L. E. Sommers, "Chemical composition of sewage sludges and analysis of their potential use as fertilizers," Journal of Environmental Quality, vol. 6, no. 2, pp. 225-232, 1977.
[17] K. Tubail, L. Chen, F. C. Michel et al., "Gypsum additions reduce ammonia nitrogen losses during composting of dairy manure and biosolids," Compost Science and Utilization, vol. 16, no. 4, pp. 285-293, 2008.

[18] M. A. Shepherd and P. J. Withers, "Phosphorus leaching from liquid digested sewage sludge applied to sandy soils," Journal of Agricultural Science, vol. 136, no. 4, pp. 433-441, 2001.

[19] Z. Dou, J. D. Toth, D. T. Galligan, C. F. Ramberg, and J. D. Ferguson, "Laboratory procedures for characterizing manure phosphorus," Journal of Environmental Quality, vol. 29, no. 2, pp. 508-514, 2000.

[20] B. Ajiboye, O. O. Akinremi, and G. J. Racz, "Laboratory characterization of phosphorus in fresh and oven-dried organic amendments," Journal of Environmental Quality, vol. 33, no. 3, pp. 1062-1069, 2004.

[21] Z. L. He, A. K. Alva, D. V. Calvert, Y. C. Li, P. J. Stoffella, and D. J. Banks, "Nutrient availability and changes in microbial biomass of organic amendments during field incubation," Compost Science and Utilization, vol. 8, no. 4, pp. 293-302, 2000.

[22] G. Logsdon, “Beneficial biosolids," Biocycle, vol. 34, no. 2, pp. 42-44, 1993.

[23] P. R. Warman and W. C. Termeer, "Evaluation of sewage sludge, septic waste and sludge compost applications to corn and forage: $\mathrm{Ca}, \mathrm{Mg}, \mathrm{S}, \mathrm{Fe}, \mathrm{Mn}, \mathrm{Cu}, \mathrm{Zn}$ and $\mathrm{B}$ content of crops and soils," Bioresource Technology, vol. 96, no. 9, pp. 10291038, 2005.

[24] R. Moral, J. Moreno-Caselles, M. Perez-Murcia, and A. PerezEspinosa, "Improving the micronutrient availability in calcareous soils by sewage sludge amendment," Communications in Soil Science and Plant Analysis, vol. 33, no. 15-18, pp. 3015-3022, 2002.

[25] M. Ozores-Hampton, P. A. Stansly, and T. P. Salame, "Soil chemical, physical, and biological properties of a sandy soil subjected to long-term organic amendments," Journal of Sustainable Agriculture, vol. 35, no. 3, pp. 243-259, 2011.

[26] M. A. Garau, M. T. Felipo, and M. C. Ruiz De Villa, "Nitrogen mineralization of sewage sludges in soils," Journal of Environmental Quality, vol. 15, no. 3, pp. 225-228, 1986.

[27] H. Wang, M. O. Kimberley, and M. Schlegelmilch, "Biosolids-derived nitrogen mineralization and transformation in forest soils," Journal of Environmental Quality, vol. 32, no. 5, pp. 1851-1856, 2003.

[28] L. M. Zibilske, "Temperature effects on the decomposition of paper mill sludges in soil," Soil Science, vol. 162, no. 3, pp. 198-204, 1997.

[29] R. J. Haynes, G. Murtaza, and R. Naidu, "Chapter 4 Inorganic and organic constituents and contaminants of biosolids. Implications for land application," Advances in Agronomy, vol. 104, pp. 165-267, 2009.

[30] NEBRA (North East Biosolids and Residuals Association), "A National Biosolids Regulation, Quality, End use and Disposal Survey-Preliminary Report, April 14, 2007. North EastBiosolids and Residuals Association Web," 2007, http:// www.nebiosolids.org/uploads/pdf/NtlBiosolidsReport20July07.pdf.

[31] Committee on Toxicants and Pathogens in Biosolids Applied to Land and National Research Council, Eds., Biosolids Applied To Land: Advancing Standards and Practices, National Academies Press, 2002.

[32] J. M. Tisdall and J. M. Oades, "Organic matter and waterstable aggregates in soils," Journal of Soil Science, vol. 33, no. 2, pp. 141-163, 1982. 
[33] P. J. Stoffella, M. Ozores-Hampton, N. E. Roe, Y. C. Li, and T. A. Obreza, "Compost utilization in vegetable crop production systems," Acta Horticulturae, vol. 607, pp. 125128, 2003.

[34] R. Krause, "Physical properties of soil improved by organic sludge. physical properties of agricultural materials and products," in Proceedings of the 3rd International Conference, pp. 19-23, 1985, Prague Czech Republic, August 1988.

[35] B. J. Lindsay and T. J. Logan, "Field response of soil physical properties to sewage sludge," Journal of Environmental Quality, vol. 27, no. 3, pp. 534-542, 1998.

[36] F. García-Orenes, C. Guerrero, J. Mataix-Solera, J. NavarroPedreño, I. Gómez, and J. Mataix-Beneyto, "Factors controlling the aggregate stability and bulk density in two different degraded soils amended with biosolids," Soil and Tillage Research, vol. 82, no. 1, pp. 65-76, 2005.

[37] T. Punshon, D. C. Adriano, and J. T. Weber, "Restoration of drastically eroded land using coal fly ash and poultry biosolid," Science of the Total Environment, vol. 296, no. 1-3, pp. 209-225, 2002.

[38] H. Kirchmann and M. H. Gerzabek, "Pore size changes in a long-term field experiment with organic amendments," in Soil Mineral Organic Matter Microorganism Interactions and Ecosystem Health: Dynamics, Mobility and Transformation of Pollutants and Nutrients, A. Violante, P. M. Huang, J. M. Bollag, and L. Gianfreda, Eds., pp. 419-423, Elsevier Science B.V., Amsterdam, Netherlands, 2002.

[39] M. Pagliai and L. V. Antisari, "Influence of waste organic matter on soil micro- and macrostructure," Bioresource Technology, vol. 43, no. 3, pp. 205-213, 1993.

[40] R. Khaleel, K. R. Reddy, and M. R. Overcash, "Changes in soil physical properties due to organic waste applications: a review," Journal of Environmental Quality, vol. 10, no. 2, pp. 133-141, 1981.

[41] C. Parat, R. Chaussod, J. Lévêque, and F. Andreux, "Longterm effects of metal-containing farmyard manure and sewage sludge on soil organic matter in a fluvisol," Soil Biology and Biochemistry, vol. 37, no. 4, pp. 673-679, 2005.

[42] N. T. Basta, R. Gradwohl, K. L. Snethen, and J. L. Schroder, "Chemical immobilization of lead, zinc, and cadmium in smelter-contaminated soils using biosolids and rock phosphate," Journal of Environmental Quality, vol. 30, no. 4, pp. 1222-1230, 2001.

[43] S. L. Brown, C. L. Henry, R. Chaney, H. Compton, and P. S. DeVolder, "Using municipal biosolids in combination with other residuals to restore metal-contaminated mining areas," Plant and Soil, vol. 249, no. 1, pp. 203-215, 2003.

[44] T. Baumgartl and R. Horn, "Effect of aggregate stability on soil compaction," Soil and Tillage Research, vol. 19, no. 2-3, pp. 203-213, 1991.

[45] C. Loschinkohl and M. J. Boehm, "Composted biosolids incorporation improves turfgrass establishment on disturbed urban soil and reduces leaf rust severity," HortScience, vol. 36, no. 4, pp. 790-794, 2001.

[46] M. E. W. Sydnor and E. F. Redente, "Reclamation of highelevation, acidic mine waste with organic amendments and topsoil," Journal of Environmental Quality, vol. 31, no. 5, pp. 1528-1537, 2002.

[47] S. Brown, M. Sprenger, A. Maxemchuk, and H. Compton, "Ecosystem function in alluvial tailings after biosolids and lime addition," Journal of Environmental Quality, vol. 34, no. 1, pp. 139-148, 2005.

[48] S. Brown, K. Kurtz, A. Bary, and C. Cogger, "Quantifying benefits associated with land application of organic residuals in Washington State," Environmental Science and Technology, vol. 45, pp. 7451-7458, 2011.

[49] K. Lombard, M. O’Neill, R. Heyduck et al., "Composted biosolids as a source of iron for hybrid poplars (Populus sp.) grown in northwest New Mexico," Agroforestry Systems, vol. 81, no. 1, pp. 45-56, 2011.

[50] D. L. Binder, A. Dobermann, D. H. Sander, and K. G. Cassman, "Biosolids as nitrogen source for irrigated maize and rainfed sorghum," Soil Science Society of America Journal, vol. 66, no. 2, pp. 531-543, 2002.

[51] T. A. Obreza and M. Ozores-Hampton, "Management of organic amendments in Florida citrus production systems," Annual Proceedings Soil and Crop Science Society of Florida, no. 59, pp. 22-27, 2000.

[52] F. H. Jaber, S. Shukla, P. J. Stoffella, T. A. Obreza, and E. A. Hanlon, "Impact of organic amendments on groundwater nitrogen concentrations for sandy and calcareous soils," Compost Science and Utilization, vol. 13, no. 3, pp. 194-202, 2005.

[53] D. M. Sullivan, S. C. Fransen, C. G. Cogger, and A. I. Bary, "Biosolids and dairy manure as nitrogen sources for prairiegrass on a poorly drained soil," Journal of Production Agriculture, vol. 10, no. 4, pp. 589-596, 1997.

[54] N. M. Awad and K. S. M. Fawzy, "Assessment of sewage sludge application on microbial diversity, soil properties, and quality of wheat plants grown in a sandy soil," Annals of Agricultural Science Cairo, vol. 49, pp. 485-499, 2004.

[55] Y. Luo and P. Christie, "Alleviation of soil acidity and aluminium phytotoxicity in acid soils by using alkalinestabilised biosolids," Pedosphere, vol. 12, no. 2, pp. 185-188, 2002.

[56] P. Christie, D. L. Easson, J. R. Picton, and S. C. P. Love, "Agronomic value of alkaline-stabilized sewage biosolids for spring barley," Agronomy Journal, vol. 93, no. 1, pp. 144-151, 2001.

[57] B. L. Pierce, E. F. Redente, K. A. Barbarick, R. B. Brobst, and P. Hegeman, "Plant biomass and elemental changes in shrubland forages following biosolids application," Journal of Environmental Quality, vol. 27, no. 4, pp. 789-794, 1998.

[58] J. E. Miltimore and J. L. Mason, "Copper to molybdenum ratio and molybdenum and copper concentrations in ruminant feeds," Canadian Journal of Animal Science, vol. 51, pp. 193-200, 1971.

[59] S. B. Sterrett, "Composts as horticultural substrates for vegetable transplant production," in Compost Utilization in Horticultural Cropping Systems, P. J. Stoffella and B. A. Kahn, Eds., pp. 227-240, CRC Press, Boca Raton, Fla, USA, 2001.

[60] S. B. Sterrett, C. W. Reynolds, and F. D. Schales, "Transplant quality, yield, and heavy-metal accumulation of tomato, muskmelon, and cabbage grown in media containing sewage sludge compost," Journal of the American Society for Horticultural Science, vol. 108, no. 1, pp. 36-41, 1983.

[61] A. Falahi-Ardakani, J. C. Bouwkamp, F. R. Gouin, and R. L. Chaney, "Growth response and mineral uptake of vegetable transplants grown in a composted sewage sludge amended medium. I. Nutrient supplying power of the medium," Journal of Environmental Horticulture, vol. 5, no. 3, pp. 107112, 1987.

[62] C. S. Vavrina, "Municipal solid waste materials as soilless media for tomato transplants: field production results," Proceedings of the Florida State Horticultural Society, vol. 108, pp. 232-234, 1995.

[63] J. R. Purman and F. R. Gouin, "Influence of compost aging and fertilizer regimes on the growth of bedding 
plants, transplants and poinsettia," Journal of Environmental Horticulture, vol. 10, pp. 52-54, 1992.

[64] M. Ozores-Hampton, T. A. Obreza, and G. Hochmuth, "Using composted wastes on florida vegetable crops," HortTechnology, vol. 8, no. 2, pp. 130-137, 1998.

[65] R. Rynk and N. Goldstein, "Reducing odor impacts at land application sites," BioCycle, vol. 44, no. 4, pp. 54-58, 2003.

[66] A. Sharpley, J. J. Meisinger, A. Breeuwsma, J. T. Sims, T. C. Daniel, and J. S. Schepers, "Impacts of animal manure management on ground and surface water quality," in Animal Waste Utilization: Effective Use of Manure as a Soil Resource, J. L. Hatfield, Stewart, and B. A, Eds., pp. 173-242, Ann Arbor Press, Chelsea, Mich, USA, 1998.

[67] G. A. O'Connor, D. Sarkar, S. R. Brinton, H. A. Elliott, and F. G. Martin, "Phytoavailability of biosolids phosphorus," Journal of Environmental Quality, vol. 33, no. 2, pp. 703-712, 2004.

[68] C. J. Penn and J. T. Sims, "Phosphorus forms in biosolidsamended soils and losses in runoff: effects of wastewater treatment process," Journal of Environmental Quality, vol. 31, no. 4, pp. 1349-1361, 2002.

[69] P. J. A. Withers, S. D. Clay, and V. G. Breeze, "Phosphorus transfer in runoff following application of fertilizer, manure, and sewage sludge," Journal of Environmental Quality, vol. 30, no. 1, pp. 180-188, 2001.

[70] P. S. Hooda, "Relating soil phosphorus indices to potential phosphorus release to water," Journal of Environmental Quality, vol. 29, no. 4, pp. 1166-1171, 2000.

[71] V. D. Nair and W. G. Harris, "A capacity factor as an alternative to soil test phosphorus in phosphorus risk assessment," New Zealand Journal of Agricultural Research, vol. 47, no. 4, pp. 491-497, 2004.

[72] V. D. Nair, K. M. Portier, D. A. Graetz, and M. L. Walker, "An environmental threshold for degree of phosphorus saturation in sandy soils," Journal of Environmental Quality, vol. 33, no. 1, pp. 107-113, 2004.

[73] M. C. Pautler and J. T. Sims, "Relationships between soil test phosphorus, soluble phosphorus, and phosphorus saturation in Delaware soils," Soil Science Society of America Journal, vol. 64, no. 2, pp. 765-773, 2000.

[74] L. Khiari, L. E. Parent, A. Pellerin et al., "An agrienviromnental phosphorus saturation index for acid coarsetextured soils," Journal of Environmental Quality, vol. 29, no. 5, pp. 1561-1567, 2000.

[75] P. Lu and G. A. O'Connor, "Biosolids effects on phosphorus retention and release in some sandy Florida soils," Journal of Environmental Quality, vol. 30, no. 3, pp. 1059-1063, 2001.

[76] U.S. EPA, "Edition of the drinking water standards and health advisoriess," Tech. Rep. EPA-822-R-02-038, Office of Water, Washington, DC, USA, 2002.

[77] C. M. Brenton, E. B. Fish, and R. Mata-González, "Macronutrient and trace element leaching following biosolids application on semi-arid rangeland soils," Arid Land Research and Management, vol. 21, no. 2, pp. 143-156, 2007.

[78] C. Santibáñez, R. Ginocchio, and M. Teresa Varnero, "Evaluation of nitrate leaching from mine tailings amended with biosolids under Mediterranean type climate conditions," Soil Biology and Biochemistry, vol. 39, no. 6, pp. 1333-1340, 2007.

[79] R. Stehouwer, R. L. Day, and K. E. Macneal, "Nutrient and trace element leaching following mine reclamation with biosolids," Journal of Environmental Quality, vol. 35, no. 4, pp. 1118-1126, 2006.

[80] R. C. Stehouwer and K. E. Macneal, "Effect of AlkalineStabilized Biosolids on Alfalfa Molybdenum and Copper
Content," Journal of Environmental Quality, vol. 33, no. 1, pp. 133-140, 2004.

[81] S. M. Ross, "Retention, transformation and mobility of toxic metals in soils," in Toxic Metals in Soil-Plant Systems, S. M. Ross, Ed., pp. 63-152, John Wiley \& Sons, Chichester, UK, 1994.

[82] R. H. Dowdy, J. J. Latterell, T. D. Hinesly, R. B. Grossman, and D. L. Sullivan, "Trace metal movement in an Aeric Ochraqualf following 14 years of annual sludge applications," Journal of Environmental Quality, vol. 20, no. 1, pp. 119-123, 1991.

[83] A. C. Chang, J. E. Warneke, A. L. Page, and L. J. Lund, "Accumulation of heavy metals in sewage sludge-treated soils," Journal of Environmental Quality, vol. 13, no. 1, pp. 8791, 1984.

[84] M. B. McBride, K. A. Barrett, B. Kim, and B. Hale, "Cadmium sorption in soils 25 years after amendment with sewage sludge," Soil Science, vol. 171, no. 1, pp. 21-28, 2006.

[85] A. D. Karathanasis and D. W. Ming, "Colloid-mediated transport of metals associated with lime-stabilized biosolids," in Soil Mineral Organic Matter Microorganism Interactions and Ecosystem Health: Dynamics, Mobility and Transformation of Pollutants and Nutrients, A. Violante, P. M. Huang, J. M. Bollag, and L. Gianfreda, Eds., Elsevier Science B.V., Amsterdam, Netherlands, 2002.

[86] A. D. Karathanasis and D. M. C. Johnson, "Subsurface transport of Cd, Cr, and Mo mediated by biosolid colloids," Science of the Total Environment, vol. 354, no. 2-3, pp. 157$169,2006$.

[87] P. H. T. Beckett, R. D. Davis, and P. Brindley, “The disposal of sewage sludge onto farmland: the scope of the problem of toxic elements," Water Pollution Control, vol. 78, no. 4, pp. 419-445, 1979.

[88] M. B. McBride, "Toxic metal accumulation from agricultural use of sludge: are USEPA regulations protective?" Journal of Environmental Quality, vol. 24, no. 1, pp. 5-18, 1995.

[89] A. C. Chang, H. N. Hyun, and A. L. Page, "Cadmium uptake for Swiss chard grown on composted sewage sludge treated field plots: plateau or time bomb?" Journal of Environmental Quality, vol. 26, no. 1, pp. 11-19, 1997.

[90] S. P. McGrath, A. M. Chaudri, and K. E. Giller, "Long-term effects of metals in sewage sludge on soils, microorganisms and plants," Journal of Industrial Microbiology, vol. 14, no. 2, pp. 94-104, 1995.

[91] S. P. McGrath, A. M. Chaudri, and K. E. Giller, "Longterm effects of land application of sewage sludge: soils, microorganisms and plants," in Proceedings of the 15th World Congress of Soil Science, pp. 10-16, Acapulco, Mexico, July 1994.

[92] S. P. McGrath, "Effects of heavy metals from sewage sludge on soil microbes in agricultural ecosystems," in Toxic Metals in Soil-Plant Systems, S. M. Ross, Ed., pp. 247-274, John Wiley \& Sons, Chichester, UK, 1994.

[93] H. Zerzghi, J. P. Brooks, C. P. Gerba, and I. L. Pepper, "Influence of long-term land application of Class B biosolids on soil bacterial diversity," Journal of Applied Microbiology, vol. 109, no. 2, pp. 698-706, 2010.

[94] W. Giger, "Occurrence and behaviour of detergent-derived contaminants in sewage sludge," in Specialty Conference on Management and Fate of Toxic Organics in Sludge Applied to Land, Copenhagen, Denmark, April 1997.

[95] E. F. Davis, S. L. Klosterhaus, and H. M. Stapleton, "Measurement of flame retardants and triclosan in municipal sewage 
sludge and biosolids," Environment International, vol. 40, pp. $1-7,2012$.

[96] Y. Y. Yang, J. L. Gray, E. T. Furlong, J. G. Davis, R. C. ReVello, and T. Borch, "Steroid hormone runoff from agricultural test plots applied with municipal biosolids," Environmental Science and Technology, vol. 46, pp. 2746-2754, 2012.

[97] A. B. Lindstrom, M. J. Strynar, A. D. Delinsky et al., "Application of WWTP biosolids and resulting perfluorinated compound contamination of surface and well water in Decatur, Alabama, USA," Environmental Science and Technology, vol. 45, pp. 8015-8021, 2011.

[98] E. Epstein, "Human pathogens: hazards, controls, and precautions in compost," in Compost Utilization in Horticultural Cropping Systems, P. J. Stoffella and B. A. Kahn, Eds., chapter 17, pp. 361-380, CRC Press, Boca Raton, Fla, USA, 2001.

[99] R. Iranpour and H. H. J. Cox, "Recurrence of fecal coliforms and Salmonella species in biosolids following thermophilic anaerobic digestion," Water Environment Research, vol. 78, no. 9, pp. 1005-1012, 2006.

[100] Y. Qi, S. K. Dentel, and D. S. Herson, "Increases in fecal coliform bacteria resulting from centrifugal dewatering of digested biosolids," Water Research, vol. 41, no. 3, pp. 571$580,2007$.

[101] J. L. Lemunyon and R. G. Gilbert, "The concept and need for a phosphorus assessment tool," Journal of Production Agriculture, vol. 6, pp. 449-450, 1993.

[102] V. D. Nair and D. A. Graetz, "Agroforestry as an approach to minimizing nutrient loss from heavily fertilized soils: the Florida experience," Agroforestry Systems, vol. 61-62, no. 1-3, pp. 269-279, 2004.

[103] Z. L. He, D. V. Calvert, A. K. Alva, Y. C. Li, P. J. Stoffella, and D. J. Banks, "Nitrogen transformation and ammonia volatilization from biosolids and compost applied to calcareous soil," Compost Science and Utilization, vol. 11, no. 1, pp. 81-88, 2003.

[104] G. K. Evanylo, "Effects of biosolids application timing and soil texture on nitrogen availability for corn," Communications in Soil Science and Plant Analysis, vol. 34, no. 1-2, pp. 125-143, 2003.

[105] M. S. Yoo and B. R. James, "Zinc extractability as a function of pH in organic waste-amended soils," Soil Science, vol. 167, no. 4, pp. 246-259, 2002.

[106] N. Wu and J. E. Smith, "Reducing pathogen and vector attraction for biosolids," Biocycle, vol. 40, pp. 59-61, 1999.

[107] J. A. Ippolito, K. A. Barbarick, and E. F. Redente, "Combinations of water treatment residuals and biosolids affect two range grasses," Communications in Soil Science and Plant Analysis, vol. 33, no. 5-6, pp. 831-844, 2002.

[108] G. Murtaza, R. J. Haynes, R. Naidu et al., "Natural attenuation of $\mathrm{Zn}, \mathrm{Cu}, \mathrm{Pb}$ and $\mathrm{Cd}$ in three biosolids-amended soils of contrasting $\mathrm{pH}$ measured using rhizon pore water samplers," Water, Air and Soil Pollution, vol. 221, no. 1-4, pp. 351-363, 2011.

[109] K. G. Robinson, C. H. Robinson, L. A. Raup, and T. R. Markum, "Public attitudes and risk perception toward land application of biosolids within the south-eastern United States," Journal of Environmental Management, vol. 98, pp. 29-36, 2012. 

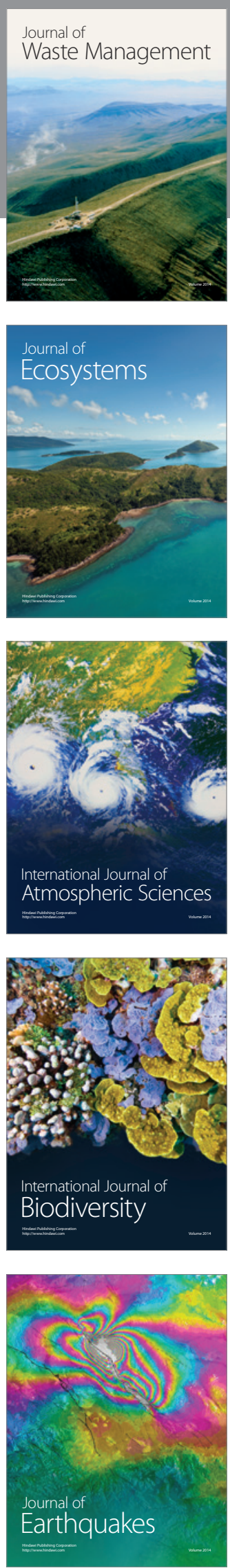
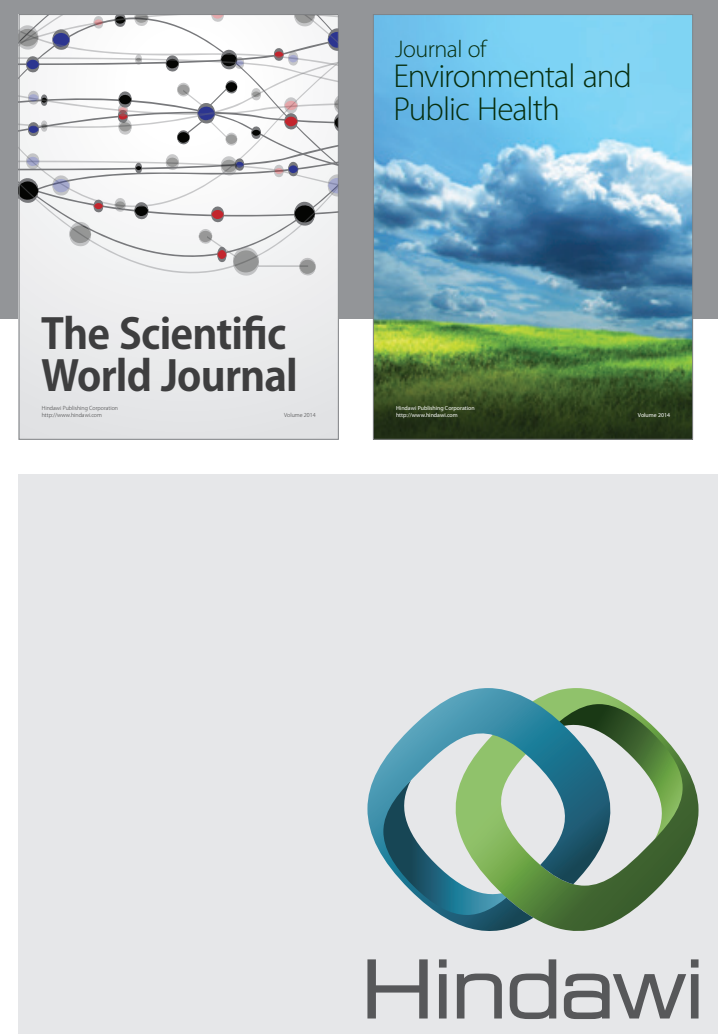

Submit your manuscripts at

http://www.hindawi.com
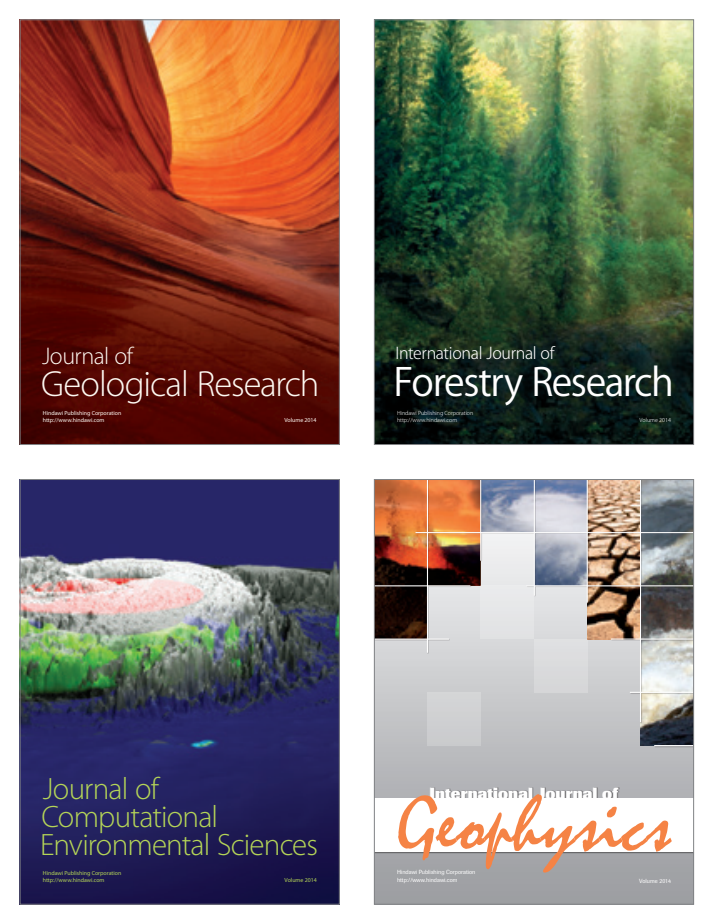
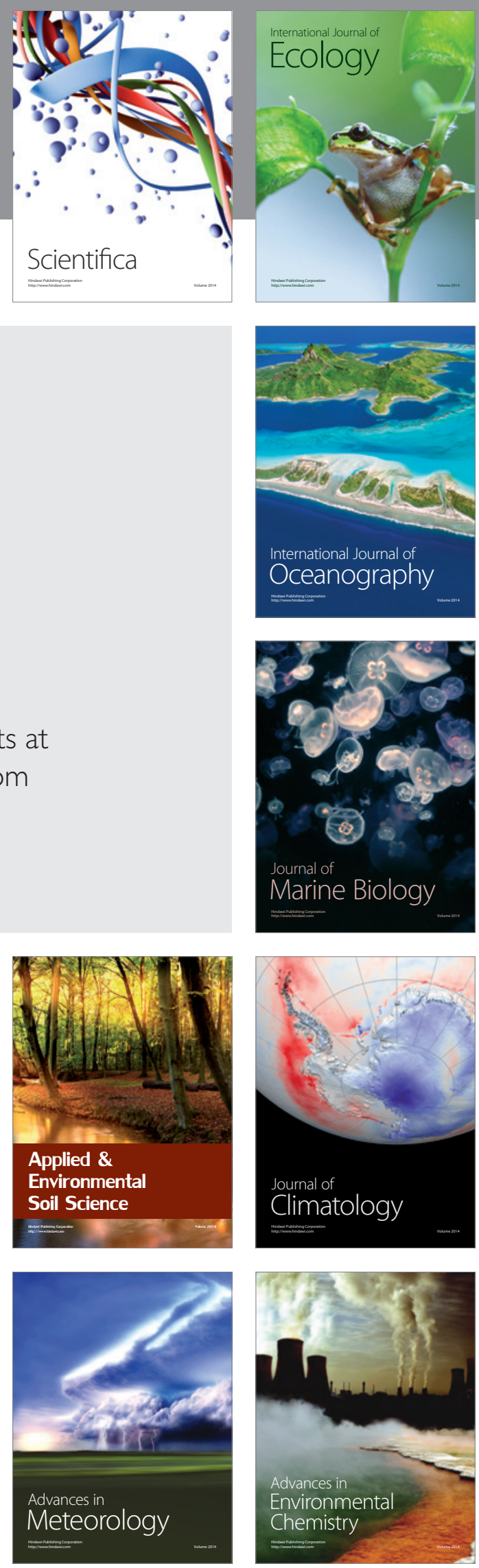